•编者按・

\title{
通过现存屏类植物多样性透视陆生植物的演化
}

\author{
严岳鸿 ${ }^{1 *}$ 卫 然 $^{2}$ 舒江平 $^{3}$ 张宪春 $^{2}$ \\ 1 (中国科学院上海辰山植物科学研究中心, 上海辰山植物园, 上海 201602) \\ 2 (中国科学院植物研究所系统与进化植物学国家重点实验室, 北京 100093) \\ 3 (中国科学院华南植物园植物资源保护与可持续利用重点实验室, 广州 510650)
}

\section{Insight into evolution of land plants from living ferns and lycopods}

\begin{abstract}
Yuehong Yan $^{1 *}$, Ran Wei ${ }^{2}$, Jiangping Shu ${ }^{3}$, Xianchun Zhang ${ }^{2}$
1 Shanghai Chenshan Plant Science Research Center, Chinese Academy of Sciences, Shanghai Chenshan Botanical Garden, Shanghai 201602

2 State Key Laboratory of Systematic and Evolutionary Botany, Institute of Botany, Chinese Academy of Sciences, Beijing 100093

3 Key Laboratory of Plant Resources Conservation and Sustainable Utilization, South China Botanical Garden, Chinese Academy of Sciences, Guangzhou 510650
\end{abstract}

通常认为的蒝类植物(包括石松类和真蒝类)是 现存陆生维管植物起源最早的活化石; 但近年来随 着分子生物学的发展, 发现现存偋类植物大部分是 伴随着有花植物的兴起而新分化的类群(Schneider et al, 2004)。2014年, Science报道了瑞典科学家Benjamin Bomfleur等发现的一块亚细胞结构保存完好的 1.8 亿年前的蓱类植物化石, 对该化石的髓部及皮 层薄壁细胞处于间期的细胞核大小测量发现, 它们 与其仍然存活的近缘类群线紫其(Osmunda claytoniana) 的相应部分十分相似。Bomfleur和他的团队 认为, 该化石线紫萁在早侏罗纪时期所含的染色体 数及DNA含量基本上与现今的紫箕科蒝类植物相 同, 使得后者成为演化停滞的重要例证, 强化了硕 类植物的 “活化石”地位(Bomfleur et al, 2014)。除此 之外, 紫其科植物的其他诸多特征如羽片的形态、 孢子囊的环带特征、根状茎维管束的横切面形态等, 和数亿年前的化石植物特征相比似乎都并没有太 大的变化(Taylor et al, 2009; 图1)。正如紫萁科植物 基因组停滞演化的案例, 生物物种在演化历程中的 稳定性和延续性使得我们有机会透过现存的硕类 植物洞察早期地质时代植物世界多样性演化的奥秘。

现存硕类植物以叶形变化多样而闻名于世。美 国著名作家梭罗曾经说过, 上帝创造痥类植物的目
的就是展示他摆弄叶片的能力(God make ferns is to show what he can do with leaves)。偋类植物通过简 单的构造, 展示了其叶形的无穷变化及生活习性的 神奇。如水龙骨类植物叶背的孢子囊具有直立的环 带, 犹如一把独特的无弦之弓, 通过环带细胞气室 内气压变化的时间差异, 精巧地将孢子囊内的孢子 弹射出去(Noblin et al, 2012); 凤尾鄺科植物蜈蚣草 (Pteris vittata) 是剧毒物质砷的超级富集者, 其叶片 可以富集500余倍于土壤砷的含量(Ma et al, 2001; 陈同斌和韦朝阳, 2002)。

总之, 瘩类植物作为地球上最古老的陆生维管 植物, 在地球早期陆生植物演化中扮演着承上启下 的重要角色; 在历经 4 亿多年的演化历程中, 形成 了一系列独特的形态结构、生活习性、生理生态机 制及多样化的物种形成模式。近年来, 研究人员通 过对蒴类植物的研究揭示了许多重大的生物多样 性演化机制, 这些新发现对人们认识地球生命的演 化具有重要意义。

\section{通过䓲类植物性状的过渡性理解陆生植} 的连续性

(1)根的起源和演化。根器官的出现是植物登陆 演化史上的最重要一步, 它帮助植物固定在土地上, 

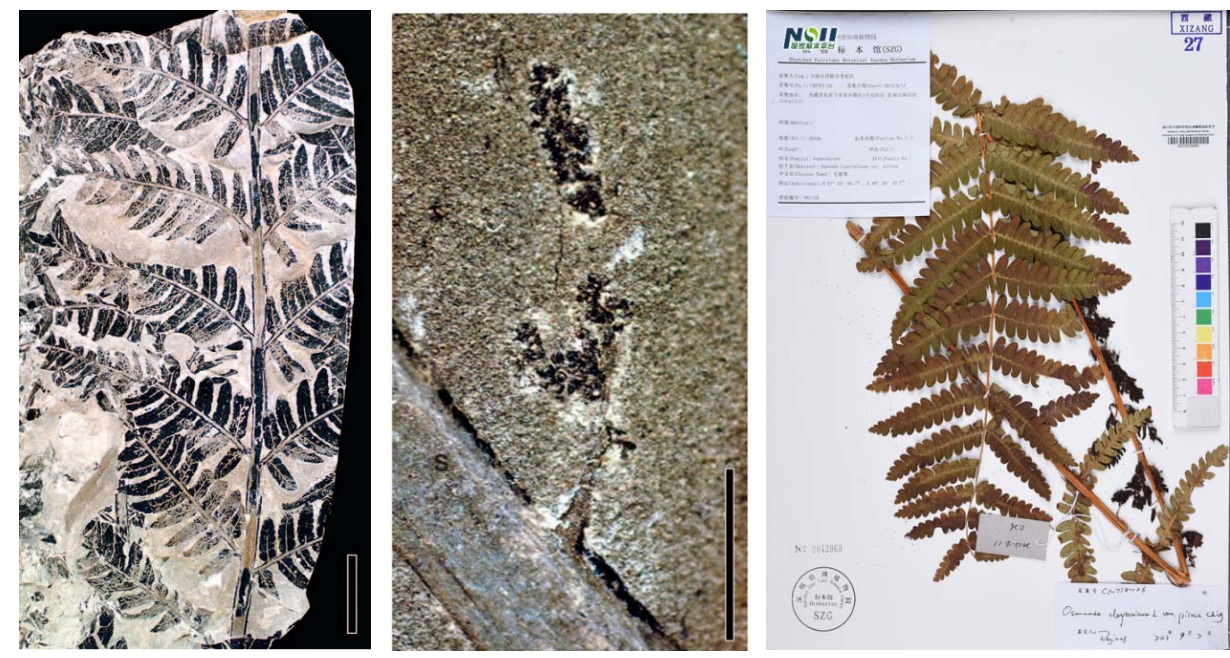

图1 产自三叠纪的线紫萁化石和现存的线紫其标本形态比较。可以看出几乎没有大的变化。图片引自Taylor et al (2009)及 NSII网站(http://www.nsii.org.cn/)。

Fig. 1 The Triassic fossil of Osmunda claytoniana remained relatively unchanged to the present. Photos from Taylor et al. (2009) and Web of NSII (http://www.nsii.org.cn/).

吸收水分和营养物质，让植物能更好地适应陆生环 境。过去, 人们认为苔藓植物不具有真正的根, 维 管植物的根始于早期登陆的石松类植物。2018年4 月18日, Trends in Plant Science在线发表了徐麟研究 组(Liu \& Xu, 2018)提出的根器官起源的IC-WOX基 因家族(intermediate-clade WOX genes)分子基础假 说, 认为现存被子植物根的发育始于真偋类植物的 侧根和不定根，而不是石松类植物简单的二歧分支 根系; 石松类的二歧根系、真偋类植物的侧根、不 定根系和种子植物千姿百态的主根系分别是3次独 立的起源。

(2)叶的起源和演化。植物登陆固定后, 首先面 临的问题就是如何进行光合作用。最早登陆的植物 是没有叶的, 只有可以进行光合作用的枝条, 人们 认为石松类叶的形成可以用突出学说 (enation theory)来解释, 真硕类和被子植物叶的起源由顶枝 学说(telome theory)来解释, 这是两次独立的起源 过程(Gifford \& Foster, 1989; Beerling \& Fleming, 2007)。但Harrison等(2005)认为, KNOX- ARP基因家 族的时空表达模式不尽相同, 石松类植物的小型叶 形成也同样与KNOX-ARP有关，在不同的植物谱系 中, 这种叶片形成的途径是独立和平行的。同时, 研究还发现大型叶片出现的驱动力可能与泥盆纪 和早石炭世 $\mathrm{CO}_{2}$ 浓度的下降有关系, 古生代时期 $\mathrm{CO}_{2}$ 浓度的下降导致大型叶的出现, 并伴随着气孔 密度的上升, 使得植物的蒸腾速率足够高而免于受
到高温的伤害(Beerling et al, 2001)。

(3)光敏色素的演化。叶片的出现解决了有机物 的生产和制造问题。植物在长期演化过程中形成了 光敏色素I和光敏色素II来分别适应强光环境和弱 光环境, 以确保实现最佳光合作用。但蕨类植物除 外，它们既对蓝光产生反应，也对红光产生反应。 这种机制对于生长在林下喜阴的偋类植物是很有 用的，因为在林下很少有蓝光穿透。光敏色素III是 蕨类植物铁线蕨(Adiantum capilla-veneris)的光感受 器, 研究发现它是两种普遍存在的光敏色素(红光 受体phytochrome和蓝光受体phototropin)的嵌合体。 光敏色素III可能是在第三纪和侏罗纪之间茂密森 林出现时形成的，是硕类植物能够适应黑暗环境的 一个关键演化步骤(Kawai et al, 2003)。

(4)气孔开合机制的演化。叶片的出现必然伴随 着进行呼吸、蒸腾作用的气孔的起源和演化。陆地 植物化石证据表明，气孔的出现可以追溯到 4 亿年 前(侯慧姣和韩鸿鹏, 2016)。在苔藓植物中, 气孔的 结构简单，其壁由单列细胞组成，气孔没有关闭能 力, 因此其气孔通常与植物水分调节功能关系不 大。Brodribb和McAdam (2011)发现䓲类植物(含石 松类)在气孔开闭过程中缺乏对脱落酸( $\mathrm{ABA}$ ) 和 $\mathrm{CO}_{2}$ 引起的气孔关闭的响应过程, 气孔开闭是被动的; 而种子植物的主动气孔控制水分平衡系统为其提 供了对干旱的适应能力，使种子植物比蒴类植物具 有更强的陆生环境生存优势(Ruszala et al, 2011)。 
2 通过蕨类植物生殖方式的原始性理解陆生 物种形成模式的多样性

物种形成是了解地球生物多样性最核心的基 础科学问题。在众多物种形成的概念和假设中, 生 殖隔离的建立是物种形成中最有标志性的过程。此 后, 新形成的种群单元开始地理扩散并建立自己的 地理分布区, 形成各自独有的性状组合以适应新的 生态位, 从而完成一个新物种的形成。蕨类植物作 为演化地位比较原始的维管植物, 其在生长发育等 各种生理机制上具有较强的可塑性, 生殖隔离的机 制并不完善, 常常表现出不同类群之间频繁的杂交 现象。即使两个隔离分化数千万年的类群之间也可 以实现自然杂交(Rothfels et al, 2015), 从而被 Nature 评述为“烣类植物杂交不介意门槛”(Nature, 518:276. 2015)。频繁的自然杂交现象, 往往会模糊 人们对物种间生殖隔离的认识, 从而模糊了物种之 间的边界, 导致许多不同支系的类群被看作是相同 的物种。

多倍化也是物种形成的一种重要方式。由于蕨 类植物生殖隔离机制的不完善, 因此多倍化在硕类 植物中非常普遍; 以至于现存偋类植物的染色体数 目非常庞大, 大部分葓类植物的染色体数目在 80-120之间, 其中瓶儿小草(Ophioglossum vulgatum) 可达1,260条或1,320条, 是目前已知生物界染色体 数目最多的物种。在现存已知的蕨类植物染色体数 据库中 (www.ccdb.tau.ac.il), 大量的䓲类植物种类 存在多倍化现象。如松叶蕨(Psilotum nudum), 目前 已知有 2 倍体 $(2 n=104) 、 3$ 倍体 $(2 n=156) 、 4$ 倍体 $(2 n$ $=208)$ 和可能的 8 倍体 $(2 n=$ c.420)。然而, 如此丰富 的倍性差异, 却仍然被分类学家视为同一物种。从 理论上来说, 这些不同倍性的种群应该具有严格的 生殖隔离, 不能简单地因为形态差异小或不同倍性 之间可以杂交而视为同一物种。

判断两个物种间是否具有生殖隔离, 一个简单的方 法是判断二者之间是否有交配后代的产生及交配 后代是否可以存活。然而无融合生殖和无性生殖方 式在硕类植物中普遍存在, 在缺乏严格的、长期的 实验观察条件下, 判断硕类植物物种间是否具有生 殖隔离机制并非易事; 单从可以杂交产生后代且后 代可以成活这个简单的自然现象很难厘清蒝类植 物的生殖隔离机制。因此, 从生殖隔离与物种形成
的角度来看, 鉴于蕨类植物普遍存在的自然杂交和 多倍化现象, 其现存物种数可能被严重低估。

\section{3 通过本专辑透视中国蒝类植物多样性研 现状}

秦仁昌院士1940年发表了水龙骨科的自然分 类，把包括现代颜类 $85 \%$ 物种的“水龙骨科”划分为 33个科(Ching, 1940), 打破了英国人Hooker统治了 一个多世纪的保守的硕类分类系统, 并且, 自此之 后中国的䓲类植物研究在世界上就一直具有重要 的影响。张开梅等(2019)通过检索Web of Science上 国内外学者发表的蒴类植物(含石松类)论文, 系统 分析了 21 世纪以来当前世界蒝类植物研究的热点 问题和方向, 结果显示中国当前仍然是硕类植物研 究的热点国家并且成果显著; 但在中外学者研究工 作的对比中, 我们也应看到当前的差距。就整个硕 类植物生物学来说, 中国的蕨类植物研究有待于开 展更为深入和系统的研究。

第一, 莿类植物基因组学研究快速发展。近年 来, 随着测序技术的发展, 石松类和蕨类植物的核 基因组、质体基因组以及线粒体基因组研究发展迅 速。目前, 已有江南卷柏(Selaginella molendorffii)、 卷柏(S. tamariscina)、满江红(Azolla pinnata)、美洲 水偋(Ceratopteris richardii)等物种的全基因组序列 发表。基因组学是当前生物学基础研究的热点, 中 国学者近年来在蒝类植物组学领域取得了一系列 重要进展。Zhang等(2019a, b)分别探讨了卷柏科叶 绿体基因组重复区的进化模式, 以及与短重复片段 在叶绿体基因组进化上的相关性。Lu等(2015)首次 利用叶绿体基因组数据重建了整个真䓲类的系统 发育框架, 使得一些关键类群间的深层系统关系, 如木贼科、瓶尔小草-松叶偋类与其他真䓲类植物, 凤尾蒴科、碗彍科与其他真水龙骨类植物, 得到了 较好地解决; Wei等(2017)以及Wei和Zhang (2020)分 别选取铁角葓亚目(Aspleniineae)以及其中的代表类 群双盖硕属(Diplazium), 利用叶绿体基因组数据揭 示了进化速率异质性和基因间系统发育的冲突信 号是造成这些疑难类群系统学问题难以解决的主 要原因, 但通过叶绿体基因组数据则可以解决多分 子片段系统发育分析所不能解决的系统学问题。在 本期专辑中, 杜新宇等(2019)系统总结了世界硕类 植物叶绿体基因组学研究领域的概况和进展, 整理 
出GenBank已经公布的石松类和蕨类植物的 175 个 质体基因组数据; 并对石松类和偋类植物的质体基 因组结构演化特征进行了系统梳理, 发现其结构变 异主要包括大片段倒位、IR区边界变动、基因或内 含子丢失等, 其中一些结构变异可作为较高分类阶 元的共衍征; 发现RNA编辑和长片段非编码序列插 入普遍存在于石松类和蕨类植物的质体基因组中。

相对于质体基因组, 转录组序列包含了更多的 物种遗传信息; 不仅可以用于系统关系的重建, 还 可以通过转录组序列信息追溯物种的适应性进化 历史。中国学者Shen等(2018)和Qi等(2018)分别独立 地利用转录组序列重建了现存蕨类植物的系统框 架。本专辑中, 汪浩等(2019)通过新测序单种科植物 翼盖偋(Didymochlaena trancatula)的转录组序列, 利用同义替换率分析发现翼盖蒝在进化历程中至 少经历了两次全基因组复制事件，两次事件的时间 (59-62 Myr和90-94 Myr)分别对应了翼盖蒝的早期 分化时间和白严纪C-T大灭绝事件的时间, 两次复 制事件促进了翼盖烣的分化和适应性进化。

第二, 偋类植物生态适应性进化研究渐成热 点。蒝类植物是自然界的奇迹, 历经数亿年的演化 子遗至今。被子植物在白严纪兴起后, 蒝类植物通 过适应被子植物森林环境而迅速爆发, 阴生硕类植 物和附生蕨类植物迅速崛起(Schneider et al, 2004; Schuettpelz \& Pryer, 2009)。附生蕨类植物是如何占 据独特的林冠层环境的? Zhang等(2019)用转录组测 序解析了附生植物鸟巢蕨(Asplenium nidus)相对于 陆生植物对开蕨(A. komarovii)适应性进化的分子机 制。而对于大部分附生䕬类植物来说，克隆生长习 性在它们的生态适应中具有重要作用, 并通过克隆 性及与附生非维管植物的相互作用共同塑造林冠 层附生植物群落(Lu et al, 2020)。本专辑中, 孙晶琦 等(2019)基于中国山地森林中蕨类植物的克隆性及 其生态适应性的研究进展, 从附生蒴类植物的根状 茎克隆生长、克隆性与生态适应性、不同克隆生长 方式与进化等方面进行综述, 探讨了蓱类植物克隆 性在森林生态系统过程与功能中的作用, 展望了今 后硕类植物生态学研究与全球变化的主流方向如 何进行结合等科学问题。

第三, 从形态学和发育生物学角度理解蒝类植 物性状演化。孢子是䓲类植物的有性生殖器官。孢 子萌发形成配子体, 配子体成熟后形成精子器和颈
卵器分别产生精子和卵, 卵受精发育成胚胎并长成 新的孢子体。蕨类植物的孢子和种子植物的花粉是 同源器官, 其表面的纹饰形态也同样复杂多样, 在 分类学和古生物学研究中具有重要意义。赵国华等 (2019)选取凤尾䕬科铁线蒴属 (Adiantum) 为材料, 用扫描电子显微镜观察孢子形态, 结合 5 个叶绿体 基因序列构建系统发育关系并探讨了孢子表面纹 饰祖先性状的演化, 结果表明蒝类植物孢子纹饰由 简单向复杂演化。蕨类植物卵的发生过程也是从简 单到复杂的演化过程(Cao et al, 2017; Dai et al, 2019); 詹㮹等(2019)首次对真水龙骨类II金星蕨科 的普通针毛颜(Macrothelypteris torresiana) 有性生殖 中的卵发生过程进行了光镜和透射电镜观察，结果 显示普通针毛硕卵发育过程中具有卵膜的出现、受 精孔的产生以及核外突等特征，与较为进化的真水 龙骨类中其他硕类植物的卵发生研究结果相似，与 薄囊㷴类中较为原始的基部类群的卵发生现象有 显著差别。

第四，物种形成研究揭开偋类植物分类困难的 谜团。由于独特的生活史过程, 自然杂交和多倍化 在偋类植物物种形成过程中扮演了重要角色。由于 生殖隔离机制的不完善, 长期以来濒类植物的物种 分类成为分类学家最为困惑的类群之一。本专辑中, 我们试图从整合分子系统学和形态学等多学科的 证据，从自然杂交和多倍化的角度理解蕨类植物的 物种形成并确定物种地位。Dong等(2019)利用转录 组数据篎选 12 个候选核基因分子标记揭示了中国 和越南产杪椤科植物中可能存在的杂交和渐渗, 并 为其中物种的重新界定和划分提供了研究基础。莫 日根高娃等(2019)通过杪椤科白杪椤(Sphaeropteris brunoniana)群体遗传学研究, 通过GBS简化基因组 测序技术获得的单核甘酸变异位点(SNP)进行系统 发育树的构建、主成分分析和遗传结构分析，并结 合数量性状的统计分析和孢子形态观察, 发现中国 产白杪椤是由白杪椤、海南白杪椤(S. hainanensis) 及二者之间的自然杂交种共同组成的复合群，恢复 了海南白杪椤的物种地位，新发现自然杂交群体广 西白杪椤(S. brunoniana $\times$ hainanensis)。梁思琪等 (2019)等研究了长期以来高度争议的铁角蕨科线裂 铁角蒝复合体(Asplenium coenobiale complex), 通 过孢粉学研究确定了该类群的生殖特性, 运用流式 细胞分析获取其倍性信息, 结合叶绿体和核基因组 
片段系统发生分析的证据, 对该类群的系统演化关 系和起源方式进行了探讨, 发现该复合群由2倍体 的多角铁角蕨(A. cornutissimum)、同原 4倍体新种马 关铁角蕨 (A. maguanense sp. nov.)及以二者为亲本 正反交形成的异源4倍体线裂铁角蕨(A. coenobiale) 和叶基宽铁角蕨(A. pulcherrimum)等4个物种组成。 多学科证据对以上两个蕨类植物复合群的解析表 明, 过去分类学家从形态学上难以处理的复合群可
能是由祖先物种及其多倍化物种、自然杂交种等多 个物种形成过程相互作用的结果。

第五，蕨类植物多样性编目工作任重道远。中 国是生物多样性大国，硕类植物多样性尤其如此。 在PPG系统中，全世界共有蕨类植物51科337属约 11,916种(PPG I, 2016), 中国科属类群多样, 以40科 178 属2,270种(含种下分类单元)的蕨类植物总数名 列世界第一(周喜乐等，2016; 图2)。中国当前相对

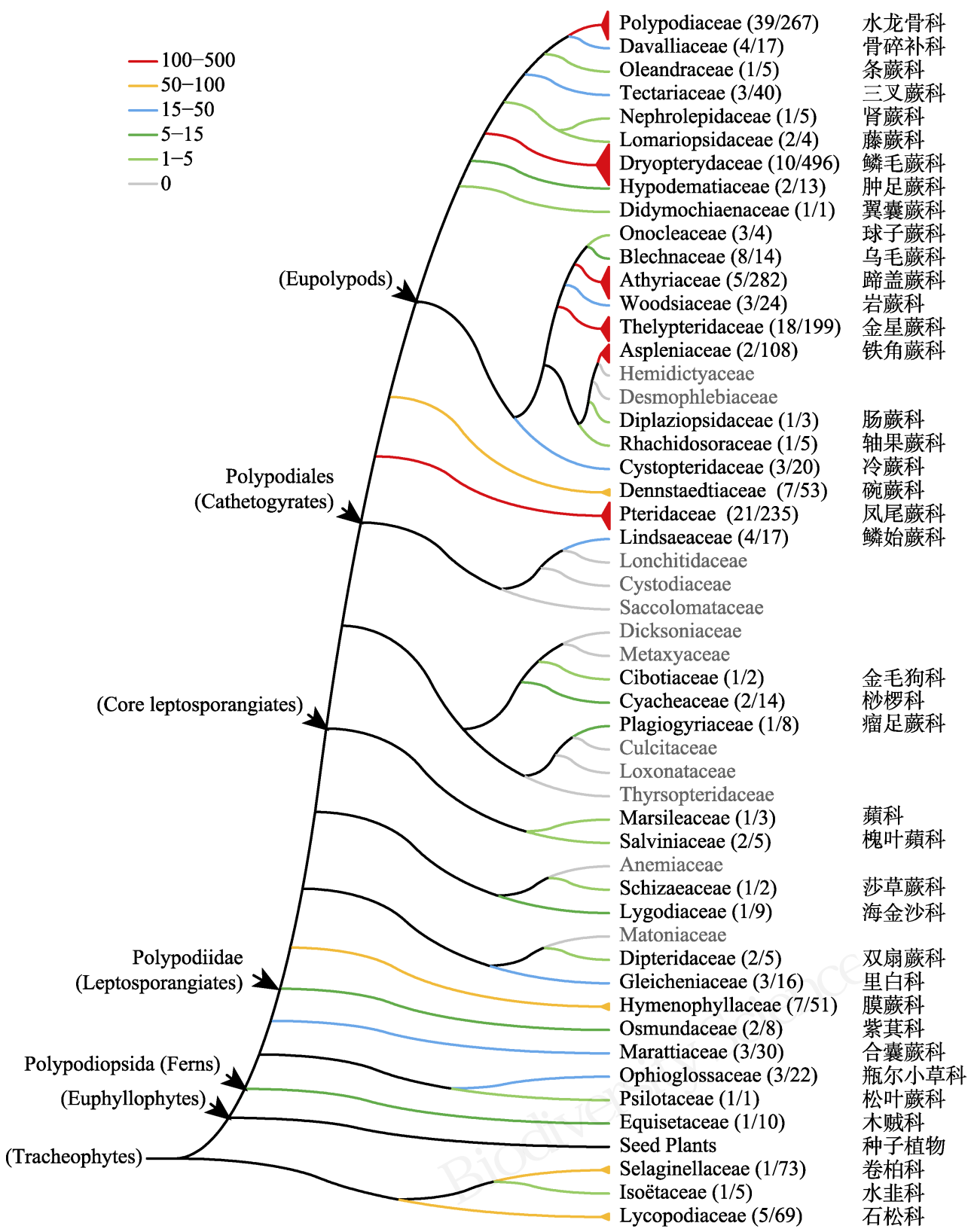

图2 中国硕类植物多样性PPG I系统(2016)概览。深色字体为中国分布类群, 括号内的数字为中国分布的属数和种数; 浅色 字体为中国没有分布的类群。

Fig. 2 Overview of ferns and lycopods in China based on PPG I (2016). Dark black words show the families distributed in China with numbers of genus and species in brackets; grey words show the families absent from China. 
完整的蕨类植物多样性编目家底得益于秦仁昌等 老一辈鄺类植物分类学家卓越而艰辛的工作; 但地 区蒴类植物多样性编目面临着人员缺乏、经费不 足、家底不清、分类和命名问题众多等诸多问题。 本专辑中, 杜维波等(2019)通过收集已出版的专著 和文献, 查阅标本馆的馆藏标本信息, 对中国西北 地区的黄土高原䓲类植物的多样性和地理分布数 据进行统计和分析, 对黄土高原硕类植物 18 科42属 165 种 2 个亚种 5 个变种进行了系统的分析, 并提供 了翔实的原始数据; 姬红利等(2019)等通过对华中 地区幕阜山脉䓲类植物资料的收集及野外调查, 整 理了 26 科 72 属 261 种蕨类植物多样性编目资料, 并 对该地区的物种组成、区系特点及其与邻近地区的 偋类植物多样性进行了比较分析。中国幅员辽阔, 生境多样, 物种丰富, 开展系统的蕨类植物多样性 编目工作仍然任重道远。

\section{参考文献}

Beerling DJ, Fleming AJ (2007) Zimmermann's telome theory of megaphyll leaf evolution: A molecular and cellular critique. Current Opinion in Plant Biology, 10, 4-12.

Beerling DJ, Osborne CP, Chaloner WG (2001) Evolution of leaf-form in land plants linked to atmospheric $\mathrm{CO}_{2}$ decline in the late paleozoic era. Nature, 410, 352-354.

Bomfleur B, McLoughlin S, Vajda V (2014) Fossilized nuclei and chromosomes reveal 180 million years of genomic stasis in royal ferns. Science, 343, 1376-1377.

Brodribb TJ, McAdam SAM (2011) Passive origins of stomatal control in vascular plants. Science, 331, 582-585.

Cao JG, Guo YD, Cao YC, Wang QX (2017) Studies on oogenesis of the fern Lygodium japonicum. American Fern Journal, 107, 124-135.

Chen TB, Wei CY, Huang ZC, Huang QF, Lu QG, Fan ZL (2002) Arsenic-accumulating plant is the characteristics of Pteris vittata and its enrichment of arsenic. Chinese Science Bulletin, 47, 207-210. (in Chinese) [陈同斌, 韦朝阳, 黄泽 春, 黄启飞, 鲁全国, 范稚莲 (2002) 砷超富集植物是蜈 蚣草及其对砷的富集特征. 科学通报, 47, 207-210.]

Ching RC (1940) On natural classification of the family "Polypodiaceae”. Sunyatsenia, 5, 201-268.

Dai XL, Bao JQ, Wang QX, Cao YC, Cao JG (2019) Ultrastructural studies of oogenesis in the fern Diplopterygium glaucum. American Fern Journal, 109, 1-10.

Dong SY, Xiao Y, Kong HH, Feng C, Harris AJ, Yan YH, Kang M (2019) Nuclear loci developed from multiple transcriptomes yield high resolution in phylogeny of scaly tree ferns (Cyatheaceae) from China and Vietnam. Molecular Phylogenetics and Evolution, 139, 106567.
Du WB, Lu Y (2019) Diversity and distribution of lycophytes and ferns in the Loess Plateau. Biodiversity Science, 27, 1260-1267. (in Chinese with English abstract) [杜维波, 卢 元 (2019) 黄土高原石松类和蕨类植物的多样性与地理 分布. 生物多样性, 27, 1260-1267.]

Du XY, Lu JM, Li DZ (2019) Advances in the evolution of plastid genome structure in lycophytes and ferns. Biodiversity Science, 27, 1172-1183. (in Chinese with English abstract) [杜新宇, 卢金梅, 李德铢 (2019) 石松类和蕨类 植物质体基因组结构演化研究进展. 生物多样性, 27, 1172-1183.]

Gifford EM, Foster AS (1989) Morphology and Evolution of Vascular Plants. Freeman, New York.

Harrison CJ, Corley SB, Moylan EC, Alexander DL, Scotland RW, Langdale JA (2005) Independent recruitment of a conserved developmental mechanism during leaf evolution. Nature, 434, 509-514.

Hou HJ, Han HP (2016) Research progress on the difference of stomata development and their regulation between monocotyledon and dicotyledon. Molecular Plant Breeding, 14, 896-903. (in Chinese with English abstract) [侯慧姣，韩鸿 鹏 (2016) 单、双子叶植物气孔发育调控差异研究进展. 分子植物育种, 14, 896-903.]

Ji HL, Zhan XH, Zhang L, Peng YS, Zhou SX, Hu W (2019) Diversity and biogeographical characteristics of lycophytes and ferns in Mufu Mountains, China. Biodiversity Science, 27, 1251-1259. (in Chinese with English abstract) [姬红利, 詹选怀, 张丽, 彭炎松, 周赛霞, 胡苑 (2019) 幕阜山脉 石松类和蕨类植物多样性及生物地理学特征. 生物多样 性, 27, 1251-1259.]

Kawai H, Kanegae T, Christensen S, Kiyosue T, Sato Y, Imaizumi T, Kadota A, Wada M (2003) Responses of ferns to red light are mediated by an unconventional photoreceptor. Nature, 421, 287-290.

Liang SQ, Zhang XC, Wei R (2019) Integrative taxonomy resolved species delimitation in a fern complex: A case study of the Asplenium coenobiale complex. Biodiversity Science, 27, 1205-1220. (in Chinese with English abstract) [梁思琪, 张宪春, 卫然 (2019) 利用整合分类学方法进 行蕨类植物复合体的物种划分：以线裂铁角硕复合体为 例. 生物多样性, 27, 1205-1220.]

Liu W, Xu L (2018) Recruitment of IC-WOX genes in root evolution. Trends in Plant Science, 23, 490-496.

Lu HZ, Brooker R, Song L, Liu WY, Sack L, Zhang JL, Yu FH (2020) When facilitation meets clonal integration in forest canopies. New Phytologist, 225, 135-142.

Lu JM, Zhang N, Du XY, Wen J, Li DZ (2015) Chloroplast phylogenomics resolves key relationships in ferns. Journal of Systematics and Evolution, 53, 448-457.

Ma LQ, Komar KM, Tu C, Zhang W, Cai Y, Kennelley ED (2001) A fern that hyperaccumulates arsenic. Nature, 409, 579.

Morigengaowa, Shang H, Liu BD, Kang M, Yan YH (2019) 
One or more species? GBS sequencing and morphological traits evidence reveal species diversification of Sphaeropteris brunoniana in China. Biodiversity Science, 27, 11961204. (in Chinese with English abstract) [莫日根高娃, 商 辉, 刘保东, 康明, 严岳鸿 (2019) 一个种还是多个种? 简化基因组及其形态学证据揭示中国白杪椤植物的物种 多样性分化. 生物多样性, 27, 1196-1204.]

Noblin X, Rojas NO, Westbrook J, Llorens C, Argentina M, Dumais J (2012) The fern sporangium: A unique catapult. Science, 335, 1322.

PPG I (2016) A community-derived classification for extant lycophytes and ferns. Journal of Systematics and Evolution, 54, 563-603.

Qi XP, Kuo LY, Guo C, Li H, Li Z, Qi J, Wang L, Hu Y, Xiang J, Zhang C, Guo J, Huang CH, Ma H (2018) A well-resolved fern nuclear phylogeny reveals the evolution history of numerous transcription factor families. Molecular Phylogenetics and Evolution, 127, 961-977.

Rothfels CJ, Johnson AK, Hovenkamp PH, Swofford DL, Roskam HC, Fraser-Jenkins CR, Windham MD, Pryer KM (2015) Natural hybridization between genera that diverged from each other approximately 60 million years ago. The American Naturalist, 185, 433-442.

Ruszala EM, Beerling DJ, Franks PJ, Chater C, Casson SA, Gray JE, Hetherington AM (2011) Land plants acquired active stomatal control early in their evolutionary history. Current Biology, 21, 1030-1035.

Schneider H, Schuettpelz E, Pryer KM, Cranfill R, Magallón S, Lupia R (2004) Ferns diversified in the shadow of angiosperms. Nature, 428, 553-557.

Schuettpelz E, Pryer KM (2009) Evidence for a Cenozoic radiation of ferns in an angiosperm-dominated canopy. Proceedings of the National Academy of Sciences, USA, 106, 11200-11205.

Shen H, Jin DM, Shu JP, Zhou XL, Lei M, Wei R, Shang H, Wei HJ, Zhang R, Liu L, Gu YF, Zhang XC, Yan YH (2018) Large scale phylogenomic analysis resolves a backbone phylogeny in ferns. GigaScience, 7(2), 1-11.

Sun JQ, Chen Q, Li HY, Chang YF, Gong HD, Song L, Lu HZ 2019) Progress on the clonality of epiphytic ferns. Biodiversity Science, 27, 1184-1195. (in Chinese with English abstract) [孙晶琦, 陈泉, 李航宇, 常艳芬, 巩合德, 宋亮, 卢华正 (2019) 附生蕨类植物的克隆性研究进展. 生物 多样性, 27, 1184-1195.]

Taylor TN, Taylor EL, Krings M (2009) Paleobotany: The Biology and Evolution of Fossil Plants, 2nd edn. Academic Press, San Diego.

Wang H, Zhang R, Zhang J, Shen H, Dai XL, Yan YH (2019) De novo transcriptome assembly reveals the whole genome duplication events of Didymochlaena trancatula. Biodiversity Science, 27, 1221-1227. (in Chinese with English abstract) [汪浩, 张锐, 张娇, 沈慧, 戴锡玲, 严岳鸿 (2019)
转录组测序揭示翼盖蕨(Didymochlaena trancatula)的全 基因组复制历史. 生物多样性, 27, 1221-1227.]

Wei R, Yan YH, Harris AJ, Kang JS, Shen H, Xiang QP, Zhang XC (2017) Plastid phylogenomics resolve deep relationships among eupolypod II ferns with rapid radiation and rate heterogeneity. Genome Biology and Evolution, 9, 1646-1657.

Wei R, Zhang XC (2020) Phylogeny of Diplazium (Athyriaceae) revisited: Resolving the backbone relationships based on plastid genomes and phylogenetic tree space analysis. Molecular Phylogenetics and Evolution, 143, 106699.

Zhan Z, Zhang JF, Cao JG, Dai XL (2019) Development of archegonium and oogenesis of the fern Macrothelypteris torresiana. Biodiversity Science, 27, 1236-1244. (in Chinese with English abstract) [詹䶍, 张剑锋, 曹建国, 戴 锡玲 (2019) 普通针毛蕨颈卵器和卵的发育. 生物多样 性, 27, 1236-1244.]

Zhang HR, Xiang QP, Zhang XC (2019a) The unique evolutionary trajectory and dynamic conformations of DR and IR/DR-coexisting plastomes of the early vascular plant Selaginellaceae (Lycophyte). Genome Biology and Evolution, 11, 1258-1274.

Zhang HR, Zhang XC, Xiang QP (2019b) Directed repeats co-occur with few short-dispersed repeats in plastid genome of a spikemoss, Selaginella vardei (Selaginellaceae, Lycopodiopsida). BMC Genomics, 20, 484.

Zhang J, Liu L, Shu JP, Jin DM, Shen H, Chen HF, Zhang R, Yan YH (2019) Transcriptomic evidence of adaptive evolution of the epiphytic fern Asplenium nidus. International Journal of Genomics, 1429316. doi.org/10.1155/2019/1429316.

Zhang KM, Shen Y, Zhou XL, Fang YM (2019) Analysis of fern research article trends across the Web of Science in the 21st Century. Biodiversity Science, 27, 1245-1250. (in Chinese with English abstract) [张开梅, 沈羽, 周晓丽, 方 炎明 (2019) 21世纪以来蕨类植物研究论文的发表情况: 基于 Web of Science 的数据统计. 生物多样性, 27, 1245-1250.]

Zhao GH, Wang Y, Shang H, Zhou XL, Wang AH, Li YF, Wang H, Liu BD, Yan YH (2019) Ancestral state reconstruction reveals the diversity and evolution of spore ornamentation in Adiantum (Pteridaceae). Biodiversity Science, 27, 12281235. (in Chinese with English abstract) [赵国华, 王芗, 商 辉, 周喜乐, 王爱华, 李玉峰, 王晖, 刘保东, 严岳鸿 (2019) 祖先性状重建法揭示铁线蕨属植物孢子表面纹饰 的形态多样性及其演化. 生物多样性, 27, 1228-1235.]

Zhou XL, Zhang XC, Sun JQ, Yan YH (2016) Diversity and distribution of lycophytes and ferns in China. Biodiversity Science, 24, 102-107. (in Chinese with English abstract) [周 喜乐, 张宪春, 孙久琼, 严岳鸿 (2016) 中国石松类和䊏 类植物的多样性与地理分布. 生物多样性, 24, 102-107.] 